\title{
What information do policy makers need to develop climate adaptation plans for smallholder farmers? The case of Central America and Mexico
}

\author{
Camila I. Donatti ${ }^{1} \cdot$ Celia A. Harvey ${ }^{1}$. \\ M. Ruth Martinez-Rodriguez ${ }^{1} \cdot$ Raffaele Vignola $^{2}$. \\ Carlos Manuel Rodriguez ${ }^{3}$
}

Received: 28 August 2015 / Accepted: 26 August 2016 / Published online: 22 September 2016

(C) The Author(s) 2016. This article is published with open access at Springerlink.com

\begin{abstract}
Scientific and technical information can increase the ability of policy makers to make strategic decisions. However, climate change policy is often formulated without significant input from science. We examine whether the availability and accessibility of information related to climate change is a major barrier for policy action on climate change adaptation for smallholder farmers. We also investigate whether scientific information related to climate
\end{abstract}

This article is part of a Special Issue on "Climate change impacts on ecosystems, agriculture and smallholder farmers in Central America" edited by Camila I. Donatti and Lee Hannah.

Electronic supplementary material The online version of this article (doi:10.1007/s10584-016-1787-x) contains supplementary material, which is available to authorized users.

Camila I. Donatti

cdonatti@conservation.org

Celia A. Harvey

charvey@conservation.org

M. Ruth Martinez-Rodriguez

rmartinez@conservation.org

Raffaele Vignola

rvignola@catie.ac.cr

Carlos Manuel Rodriguez

cmrodriguez@conservation.org

1 Conservation International, The Betty and Gordon Moore Center for Science, 2011 Crystal Dr, Suite 500, Arlington, VA 22202, USA

2 Latin American Chair of Environmental Decisions for Global Change (CLADA), Climate Change and Watershed Program, CATIE, Turrialba 7170, Costa Rica

3 Conservation International, Policy Center for Environment and Peace, 2011 Crystal Dr, Suite 500, Arlington, VA 22202, USA 
change is available and used in policy making in Central America and Mexico. Our online survey of 105 decision makers indicated that a lack of scientific and technical information hinders policy makers from developing policies to help smallholder farmers adapt to climate change. Specific needs include information on the impacts of climate change on water availability for agriculture and the areas that are or will be prone to flooding, droughts or landslides. Information about the location of the farmers who are most vulnerable to climate change, the projected temperature and precipitation in agricultural areas and the expected impacts of climate change on crop yields or animal productivity, is also needed. Despite high interest in having scientific information guide policy making, many respondents indicated that policy makers rarely use this information in adaptation planning. In addition to ensuring that relevant information is available to inform policy making, technical and scientific information must be published in venues that are readily accessible for policy makers, easy to understand, and written in a format that is policy-relevant. It is also critical that scientific articles provide specific recommendations for achieving desired policy outcomes.

\section{Introduction}

Across the world, policy makers are actively developing policies, plans and strategies to help communities adapt to the impacts of climate change (Mimura et al. 2014). The development of national climate policies and plans is complex, given the uncertainties in both climate change and its impacts. Scientific and technical information that includes representation of uncertainty can help guide the policy making process and create evidence-based policies to tackle climate change. Despite the need for climate science to inform climate policy making, there is a current disconnect between the scientific information being generated and the information needed to guide policy (Adger et al. 2007; Bushell et al. 2015). While scientists continue to produce more data and information, much of this scientific research is being generated without taking into account the needs of policy makers (Agrawala et al. 2001; Cash et al. 2003; French and Geldermann 2005; Rayner et al. 2005). In addition, policy makers often have limited time, resources or ability to review and use the scientific information that is being produced (Dabelko 2005; Morss et al. 2005; Rayner et al. 2005; Moser and Luers 2008; Heller and Zavaleta 2009). The result is that climate change policy is often formulated without significant input from science (Abbasi 2006; Sarewitz and Pielke 2007), even though policy makers are interested in incorporating research results into the policy making process (Sarachick and Shea 1997).

Few studies to date have addressed whether lack of scientific or technical information is a key barrier impeding the design and implementation of climate change adaptation policies. Likewise, few studies have examined what types of scientific information successfully inform policy making on climate change adaptation (Morss et al. 2005; Cote 2011). Here, we examine the importance of scientific or technical information in designing policies and plans to help smallholder farmers adapt to climate change. Smallholder farmers provide over $80 \%$ of the food consumed in the developing world (UNEP 2013), represent $85 \%$ of the world's farms (Nagayets 2005) and comprise $60 \%$ of the agricultural workforce worldwide (Fyfe 2002). In Latin America, smallholder farmers represent 75 million people or almost two thirds of the total rural population (Devendra 2007) and are critical for agriculture production and food security. Smallholder farmers often have few resources and limited technical capacity to maintain or increase productivity, live in environmentally fragile and remote locations and 
are highly vulnerable to the impacts of climate change (Eakin 2005; Lobell et al. 2008; Vorley et al. 2012; UNEP 2013), which exacerbates their already precarious living conditions (Morton 2007). Therefore, the adaptation of smallholder farmers to the impacts of a changing climate and the predicted increase in extreme events should be a priority for maintaining agricultural productivity under climate change and improving farmers' well-being.

Mexico and all Central American countries have developed climate change strategies (e.g. Picado Traña 2003; Ministerio de Ambiente, Energia y Telecomunicaciones 2009; Ministerio de Medio Ambiente y Recursos Naturales 2013; Ministerio Agropecuario y Forestal 2013a, b; Secretaría de Medio Ambiente y Recursos Naturales 2013; Secretaria de Recursos Naturales y Ambiente 2010). However, these documents currently lack the identification of specific plans targeting the adaptation of smallholder farmers, despite the importance of smallholder farmers for agriculture production and the urgent need for action on this front. This could be the result of the lack of information or the limited use of the available information by policy makers (Tribbia and Moser 2008; Rayner et al. 2005) that could otherwise guide the identification and implementation of specific adaptation policies targeting this group.

The goal of this paper is to investigate whether the lack of scientific or technical information is a major barrier for policy makers to take action on climate change adaptation for smallholder farmers in Central America and Mexico. The paper also assesses the needs, availability and use of scientific information related to climate change impacts by policy makers. We implemented an online survey with decision makers to address the following questions: a) Is the lack of scientific or technical information (projected changes in climate, expected impacts of climate change on farmers and farming systems and adaptation measures, strategies and practices for smallholder farmers) a barrier that prevents policy makers from taking action on climate change adaptation for smallholder farmers?; b) How important are particular types of information to guiding policy makers in the development of adaptation plans for smallholder farmers?; c) To what extent has technical or scientific information been used to develop or implement adaptation policies or plans for smallholder farmers?; and d) What gaps exist in the information? Countries in the region are in the process of updating or creating their national adaptation plans and their Intended Nationally Determined Contributions (INDCs), following the recent Paris Agreement. Therefore, this work can help make policy makers aware of existing information and scientists aware of the types of information needed to improve or develop adaptation policies and plans for smallholder farmers.

\section{Materials and methods}

To capture decision makers' views on the importance of scientific or technical information for developing adaptation policies for smallholder farmers, we designed and implemented an online survey consisting of six sections. In addition to collecting basic information on the respondent, we asked them to explain how important potential barriers were to policy making for the climate change adaptation of smallholder farmers, to identify what data and information would be helpful in policy making and to indicate how frequently this information has been used in policy making. We chose to use closed questions to shorten the length of the survey (each one took 20 min to complete) and to maximize the possibility of getting a high number of responses. A copy of the survey instrument is available in Annex 1 of the supplementary material. 
To identify potential respondents for the survey, we first identified key institutions working on agriculture and climate change issues in the region (Table 1, supplementary material) and obtained names of decision makers from their websites. We then contacted each of the decision makers from this list and used snowball sampling (Goodman 1961) to identify other potential participants recommended by them.

We sent the online survey to a total of 461 decision makers from Mexico (218), Guatemala (54), Nicaragua (49), Panama (49), Costa Rica (44), Honduras (27) and El Salvador (20) using SurveyMonkey (www.surveymonkey.com). To encourage greater participation in the survey, we sent emails to members of climate change departments or to people we met at climate change-related events. We sent up to 10 reminders to participants that did not respond to previous requests. All data were collected between August and October 2014. Table 2 (supplementary material) shows the number of requests sent and the number of complete surveys received per country. We summarized survey responses using descriptive statistics (mean, standard errors and percentages) and tested the differences in answers among countries and among job positions using ANOVA (Field 2007). All analyses were conducted in R (R Core team 2013).

To identify the availability of scientific and technical information addressed in the survey we conducted an online search in Google and Google Scholar using the key words listed in Annex 2 (supplementary material). Key words used represented a short description of each type of information asked in the survey. We considered particular information (e.g., information on climate change impacts on water resources) as available if the information was explicitly presented in a form of a detailed map or table that was specific to a Central American country or to Mexico. The search for relevant scientific information in both peerreviewed articles or grey literature (e.g. governmental or institutional reports and documents) allowed us to a) compare the perceptions of decision makers on the availability of information to what actually exists in the literature and b) identify information gaps that, when filled, could support policy making targeting the adaptation of smallholder farmers in this region.

\section{Results}

\subsection{Survey responses}

We obtained responses from 105 participants (23\% of those contacted, Table 2, supplementary material), which is an acceptable response rate for online surveys (Sheehan 2001; Kaplowitz et al. 2004). Although we sent the survey to 19 decision makers in Belize, we only received one answer and opted not to include it in our results. Survey respondents assigned themselves to five job positions (Figure 1, supplementary material). Respondents included 43 heads of unit at national level, 27 heads of unit at state level, 26 technical officers, four project managers and one minister (four respondents did not indicate their job position). The responses of the minister were included with those of the heads of unit at national level. There is a level of hierarchy across positions in terms of their activities. Heads of units at national level usually oversee national level programs, have a clear mandate for developing national policies (Ministerio de Agricultura, Ganadería y Alimentación 2011) and are more senior than heads of units at the state level. Technical officers and project managers have more technical responsibilities on the ground and provide advice to immediate higher-level positions. Survey respondents had significant experience on issues regarding agriculture (mean and 
standard error of $18.9 \pm 2.0$ years), climate change $(6.7 \pm 0.7$ years), climate change adaptation $(5.9 \pm 0.7$ years) and smallholder famers (15.6 \pm 1.7 years). The mean overall number of years of work experience of respondents was $10.6 \pm 0.5$ years.

\subsection{Barriers to policy action on adaptation for smallholder farmers}

Respondents identified a number of issues as important barriers to taking action on climate change adaptation for smallholder farmers. On average, participants identified 5.2 barriers (out of the 15 possible barriers) as being 'very important' and 5.8 as being 'important'. Barriers considered as 'very important' included the lack of information (on adaptation measures, projected climate change, and expected climate impacts), as well as barriers related to limited institutional capacity, financial support, coordination issues, lack of personnel, extension services and political will (Fig. 1). While there were differences in the relative frequency of responses for individual barriers, at least $66 \%$ of all respondents indicated that each of the fifteen potential barriers were either 'very important' or 'important' for taking action on climate change adaptation for smallholder farmers. The lack of information on adaptation measures was considered 'very important' by $46 \%$ of all respondents, while the lack of information on projected changes in climate and expected climate change impacts was considered 'very important' by $44 \%$.

The percentage of participants that identified barriers as 'very important' varied across countries $(\mathrm{F}=5.12, p<0.01$, df $=6$; Figure 2, supplementary material). The lack of information on projected climate change and climate change impacts was ranked as 'very important' by at least half of the respondents in Nicaragua (75\%), Honduras (67\%), Panama (57\%), Guatemala (52\%) and El Salvador (50\%), but by a smaller percent of respondents in Mexico (34\%) and Costa Rica (25\%). The lack of information on adaptation measures was perceived as 'very important' by more than $50 \%$ of respondents in El Salvador (75\%), Nicaragua and Honduras (67\% each), but by a smaller percent of respondents in the other countries (Guatemala: $48 \%$, Panama: $43 \%$, Mexico: $42 \%$ and Costa Rica: $31 \%$ ). In Costa

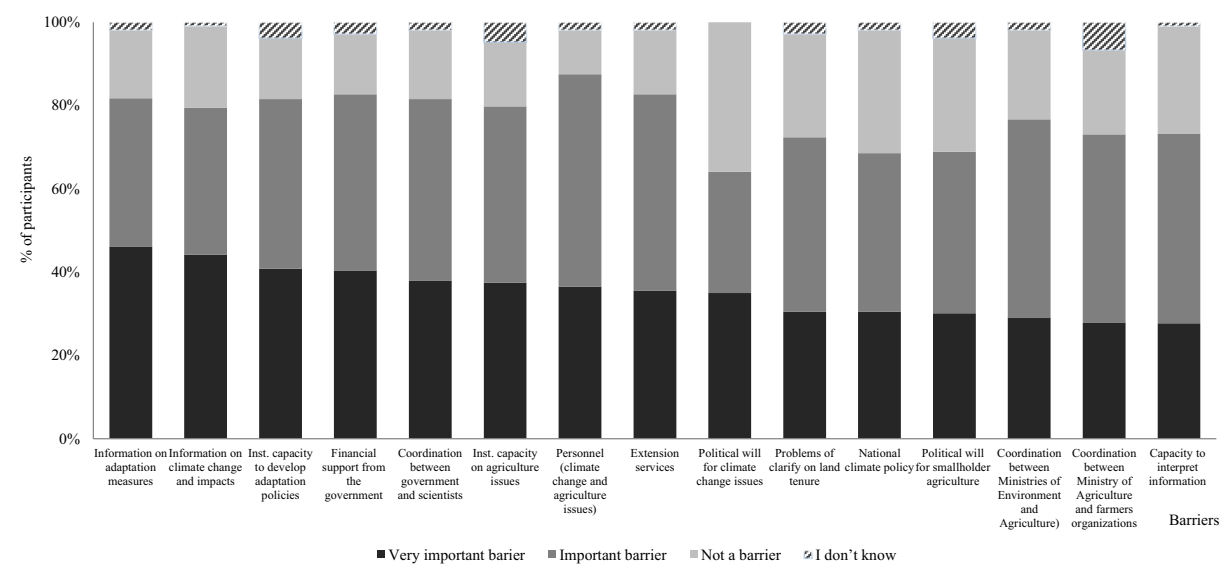

Fig. 1 The percentage of participants $(n=105)$ that identified potential barriers as 'very important', 'important' or 'not a barrier' for policy makers to take action on climate change adaptation for smallholder farmers, through the online survey 
a

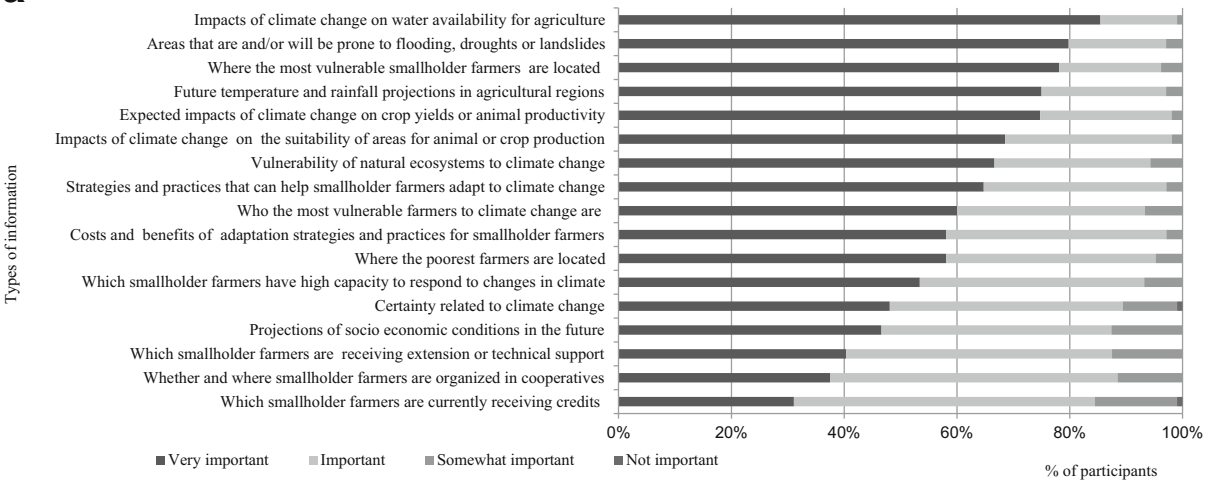

b

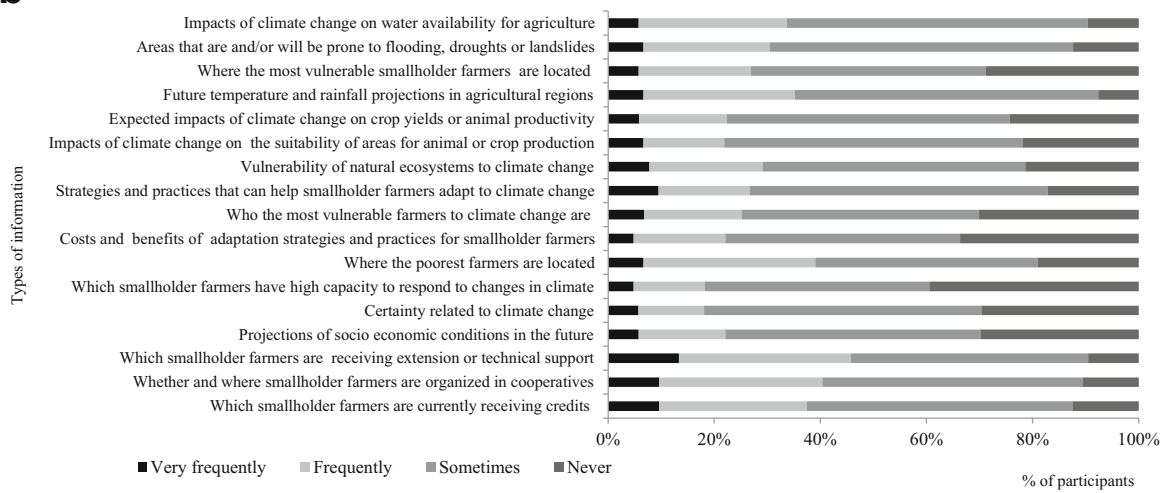

Fig. 2 a Percentage of participants $(n=105)$ that identified each type of information as 'very important', 'important', 'somewhat important', and 'not important' to support policy makers to successfully implement climate change adaptation plans for smallholder farmers. b Perception of participants $(n=105)$ that identified each type of information as 'very frequently used', 'frequently used', 'sometimes used' or 'never used' by policy makers to inform adaptation plans and programs for smallholder farmers

Rica the barriers most frequently identified as 'very important' were the lack of institutional capacity and financial support, in Guatemala the lack of financial support, in Panama the lack of political will, financial support and personnel and, in Mexico, the lack of coordination between government and scientific groups.

The percentage of participants that identified each barrier as 'very important' also varied across respondents with different job positions $(\mathrm{F}=7.252, p<0.01$, df $=3$; Figure 3, Supplementary Material). The lack of information on projected changes and impacts was ranked as a very important barrier by $48 \%$ of the heads of units at state level and by $47 \%$ of heads of units at national level but by only $35 \%$ and $25 \%$ of technical officers and project managers, respectively. The lack of information on adaptation measures, strategies and practices was seen as a very important barrier by $46 \%$ of heads of units at national level, heads of units at regional level and project managers, and by $35 \%$ of the technical officers. The lack of financial support was identified as a very important barrier by most of technical officers $(57 \%)$ and project managers $(75 \%)$ when compared to other barriers (Figure 3, supplementary material). 


\subsection{Importance of particular types of information to support policy makers in the development of adaptation policies or plans for smallholder farmers}

Respondents indicated that it was very important to have access to various types of information on expected climate change impacts, adaptation strategies, smallholder vulnerability and adaptive capacity in order to support the implementation of adaptation plans for smallholder farmers. Of the 17 types of information considered, 12 were ranked as 'very important' by more than $50 \%$ of respondents (Fig. 2a). These included information or maps on the impacts of climate change on water availability for agriculture (identified by $85 \%$ of the participants as being 'very important'), areas that are or will be prone to flooding, droughts or landslides $(80 \%)$, the location of the farmers who are most vulnerable to climate change $(78 \%)$, the projected temperature and precipitation in agricultural areas $(75 \%)$ and the expected impacts of climate change on crop yields or animal productivity $(75 \%)$. Although the use of mainly closed questions may have introduced a bias in the answers provided, we are confident that the sample size is large enough for us to have captured the general perceptions of decision makers and the relative importance of different types of information for policy making.

The percentages of participants that identified each type of information as 'very important' varied across countries $(\mathrm{F}=4.65, p<0.01$, df $=6$; Figure 4, supplementary material) but not across job positions $(\mathrm{F}=2.74, p=0.56, \mathrm{df}=3$; Figure 5, supplementary material). A high percentage of participants from all four job positions indicated that 'maps or information about projected temperature and precipitation in agricultural areas', 'maps of areas that are or will be prone to flooding, droughts or landslides' and 'maps or information on the impacts of climate change on water availability for agriculture' are very important to support decisions makers in developing adaptation plans for smallholder farmers.

\subsection{Use of technical and scientific information in the development of policies or plans for the adaptation of smallholder farmers}

Despite the fact that participants considered many types of information to be 'very important' for decision making, most of the participants (from $61 \%$ to $81 \%$ depending on the type of information, see Fig. 2b) indicated that they have rarely or never observed the information being used by policy makers to inform adaptation planning for smallholder farmers. Similarly, for the five types of information identified as 'very important' by more than $75 \%$ of the participants (see previous section), most of the participants (64\% to $77 \%$, depending on the type of information) indicated that they have rarely or never observed this information being used by policy makers.

This was true across all countries except El Salvador, where most of the participants (50 to $67 \%$, depending on the type of information) indicated that scientific information has been very frequently or frequently used by policy makers to inform adaptation planning. The discrepancy between the importance of scientific information and the limited use of this information in policy making was clear for heads of units at the national level, heads of units at the state level and technical officers (with percentages of participants that have rarely or never seen the information being used by policy makers, varying from 69 to $84 \%, 56$ to $85 \%$, and $54 \%$ to $74 \%$, respectively, depending on the type of information). For project managers, the pattern was not as clear. 


\subsection{Availability of particular types of information, according to the participants}

The percentages of participants that indicated that there is enough scientific information available to inform policy making on adaptation of smallholder farmers to climate change varied from $18 \%$ to $61 \%$, depending on the type of information considered. Forty five percent of the participants said they had sufficient information on the identification of the most vulnerable farmers in their countries. Similarly, $61 \%$ of the participants said they had sufficient information on the location of the most vulnerable farmers in their countries. However, less than $40 \%$ of participants indicated that they had sufficient information about strategies and practices that can help farmers, costs and benefits of practices, climate change and impacts, and future socioeconomic conditions.

When looking at the data by country, a high percentage of participants from Costa Rica (78\%), Mexico (63\%) and Guatemala (62\%), compared to the other countries, indicated that policy makers have sufficient information on where the most vulnerable farmers are located. In contrast, less than $50 \%$ of participants from all countries reported that policy makers have enough information about who are the most vulnerable farmers (except Panama, with $57 \%$ ), strategies and practices that can help farmers (except Costa Rica, with $57 \%$ ), costs and benefits of practices, climate change and impacts and future socio-economic conditions.

When analyzing the answers by job position, a high percentage of technical officers (58\%), project managers $(75 \%)$, heads of unit at state level (74 \%), and heads of unit at national level (54\%) indicated that policy makers have enough information about the location of the most vulnerable farmers in their countries. Less than $50 \%$ of participants in each job position indicated that policy makers have enough information on who are the most vulnerable farmers (except technical officers, with a percentage of $57 \%$, and project managers, with a percentage of $67 \%$ ), strategies and practices that can help farmers (except technical officers, $52 \%$ ), costs and benefits of practices, climate change and impacts and future socioeconomic conditions.

\subsection{Availability of particular types of information, based on online search}

In our online search, we found 128 reports, technical documents, peer-reviewed publications and policy briefs that provide specific scientific or technical information about future climate projections, expected impacts of climate change on agriculture, water availability, farming systems and biodiversity, the vulnerability of farmers, the costs and benefits of particular adaptation practices (especially agroforestry) and the management practices for coffee and cacao that could inform policy decisions in the region (Table 1; Table 3, supplementary material). There is information available for many countries about most of the issues that policy makers have indicated as being important for adaptation planning. However, the quantity and level of specificity of the existing information varies across countries, and the information is far from complete.

There is incomplete information about the location of the poorest farmers (information only exists for Nicaragua and Mexico) and the location of the most vulnerable farmers (only available for El Salvador, Nicaragua and Mexico). Information on whether or where smallholder farmers are organized in cooperatives is only available for El Salvador and Nicaragua. Information on strategies and practices that can help smallholder farmers is mainly focused on agroforestry coffee and cacao systems. In addition to the limited information available, other limitations are that many of the documents surveyed do not specifically mention policy makers as the audience (98\%), which may make documents less user-friendly to policy makers. In addition, many documents are not written or co-written by governmental bodies ( $83 \%)$, which may limit their access by policy makers, or are peer-reviewed publications (13\%), which may not be readily available to policy makers. 


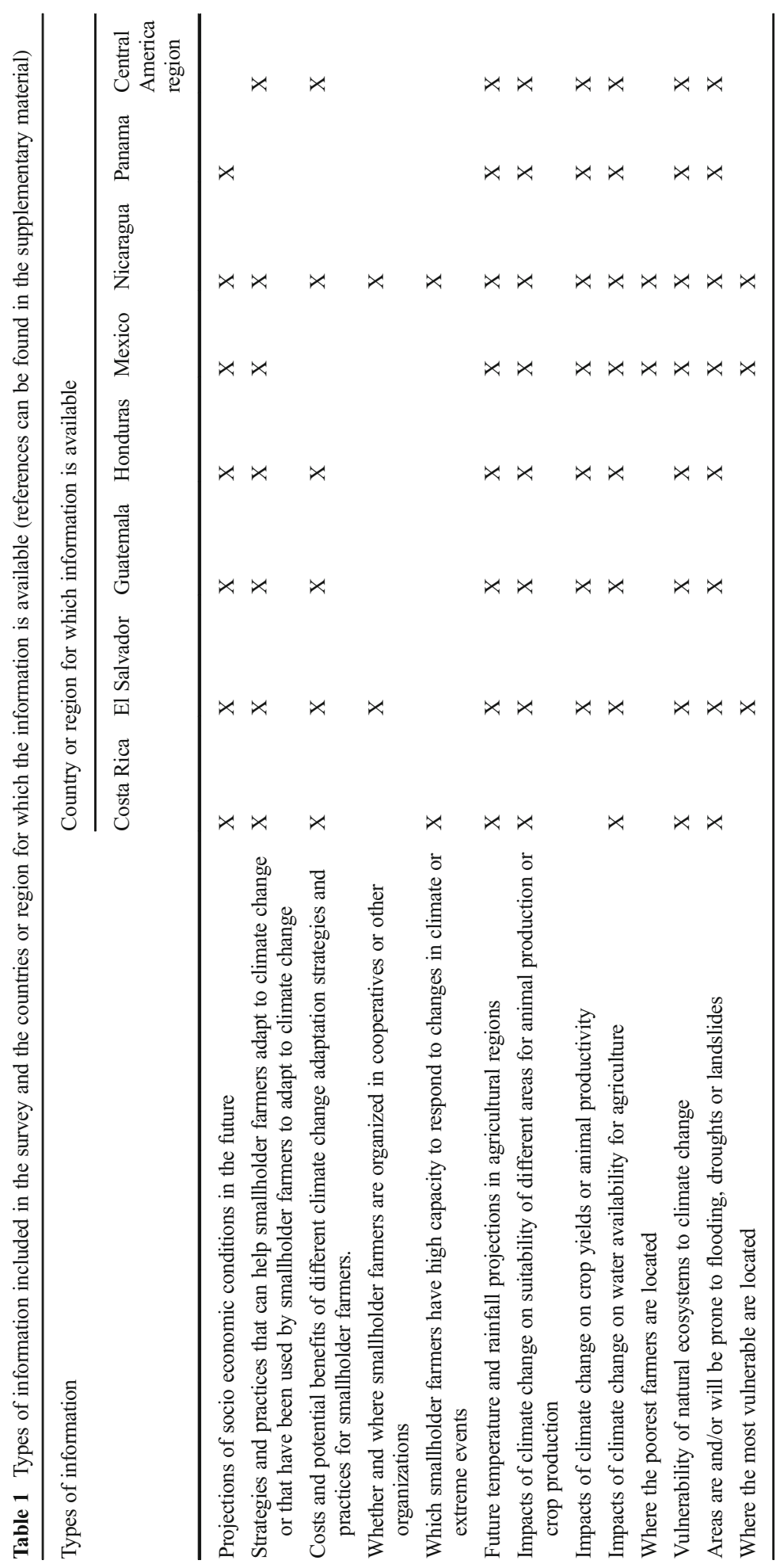




\section{Discussion}

Our survey suggests that policy makers in Central America and Mexico face a number of important barriers for developing and implementing climate change adaptation policies and plans for smallholder farmers. These barriers include the lack of information on climate change impacts and adaptation measures, lack of institutional capacity and financial support and lack of coordination between government and scientific groups. While there were differences across countries regarding the barriers identified as 'most important', the lack of technical information on the projected changes in climate, expected impacts of climate change on farmers and farming systems and adaptation measures appropriate for smallholder farmers were generally considered very important barriers for policy making by most participants. However, these results varied across countries, with Costa Rican and Mexican respondents generally indicating that the lack of information is not as important a barrier as in other countries. Costa Rica accounts for one third of the total spending on public agricultural research and development in the region (Stads 2008), and Mexico has the second highest public agricultural research spending in Latin America (Stads and Beintema 2009). This greater investment may mean that information is available or being produced. For example, in our survey, a higher percentage of participants in Costa Rica (51\%) and Mexico (42\%), when compared to the other five countries surveyed (El Salvador: $25 \%$, Guatemala: $33 \%$, Honduras: $16 \%$, Nicaragua: $31 \%$ and Panama: $25 \%$ ), indicated that policy makers in those countries have sufficient information on issues related to the vulnerability of smallholder farmers.

The lack of information seems to be a bigger concern for heads of units at both the national and state levels than for project managers and technical officers. This may reflect either that higher level decision makers identify different information needs than their technical counterparts or that they are less aware of existing scientific or technical information that could inform policy making. There were also differences across the levels of decision makers in their perception of how frequently information is used in policy making. Project managers reported that information was used much more frequently in policy making than decision makers at higher levels.

Decision makers indicated that the availability of information is very important for policy making related to smallholder farmer adaptation. Among the most valuable information are maps on the impacts of climate change on water availability for agriculture, knowledge of areas that are or will be prone to flooding, droughts or landslides, the location of the most vulnerable farmers to climate change, the projected temperature and precipitation in agricultural areas and the expected impacts of climate change on crop yields or animal productivity. Although we did not explicitly ask participants why those types of information were considered very important, information on the expected magnitude of climate change and associated impacts is critical for deciding what action is needed and what opportunities exist (Jones et al. 2014). These results also suggest that policy makers might be more interested in information that helps with planning rather than more detailed information that can be used later for on-theground implementation of adaptation strategies.

Paradoxically, although most of the participants have indicated that it is very important to have access to scientific or technical information on climate change issues and adaptation strategies, most of them also indicated that they have rarely or never observed this information being used by policy makers to inform adaptation planning for smallholder farmers. The limited use of the available scientific information in climate policy has been documented 
elsewhere (Campbell et al. 2009; Uneke et al. 2010). For example, a study with coastal managers in California found that projections of future climate change are rarely incorporated in planning decisions (Tribbia and Moser 2008).

The discrepancy between the perceived high importance of scientific or technical information for decision making and the limited use of this information in the process could be due to several reasons. First, it is possible that the information decision makers consider important for policy making is unavailable or insufficient. However, much of the information that decision makers indicate as 'very important' for helping develop policies for smallholder farmer adaptation to climate change does exist in the literature (Table 3, supplementary material). For example, maps or information on the impacts of climate change on water availability exist for Central America (e.g., Imbach et al. 2010, CEPAL 2012) as well as specifically for Mexico (WWF 2010; Gay and Estrada 2007), Honduras (UNDP 2013), El Salvador (OjedaBustamante et al. 2011) and Nicaragua (Ministerio Agropecuario y Forestal 2013a, b). Likewise, maps showing areas that are or will be prone to extreme events exist for all countries in Central America (e.g. CEPAL 2013; Maynard-Ford et al. 2008) as well as specifically for El Salvador (Crone et al. 2001) and Guatemala (Kowal and Delgado 2010). While there are some key gaps in the information available (see Section 3), there is at least some information on most of the key issues that are needed to inform adaptation policies for smallholder farmers. Therefore, while the lack of available information may constrain policy making to a certain degree, it is unlikely to be key reason for the discrepancy between the perceived importance of scientific or technical information and its limited use.

A second reason for this discrepancy could be that policy makers have limited access to the existing scientific or technical information and cannot use it to inform policy making processes. This limited access to information may be because those generating the information are publishing it in scientific journals that are not typically accessed by policy makers (Tribbia and Moser 2008), presenting it in English (rather than the local language), or in a technical format that is unappealing to policy makers (FAO 2011). In fact, of the 128 documents we reviewed, only five were written in the form of policy briefs and only 22 were written or co-written by governmental bodies. These findings suggest that there is an urgent need for scientists to make their research results more accessible, understandable and relevant to policy making in the region.

A final reason for this discrepancy may be that policy makers, especially those in higher levels, may not understand or know how to interpret and use the existing information. A study on climate change information needs of coastal managers in California showed that managers often lack the ability to incorporate weather- or climate-related information into decision making (Moser and Luers 2008). This suggests that the awareness or the availability of information about climate change impacts are insufficient for solving the management challenges that decision makers face (Moser and Luers 2008). In addition, a study that addressed the use of climate forecasts among water managers showed that the higher up the respondent is in the organization hierarchy, the less likely s/he is to understand how technical information can be used in policy making (Rayner et al. 2005). This may result from a lack of well-interpreted data or a lack of properly translated information that could otherwise facilitate the consideration of scientific and technical information into policy making. In our region, most of the literature available that we found does not have policy makers as the main audience. The lack of capacity (including time and resources) of both researchers and policy makers to interpret and translate scientific and technical information may also prevent or slow down the development of policies for the climate change adaptation of smallholder farmers. 


\section{Conclusions}

It is clear that Central American and Mexican decision makers recognize the importance of technical and scientific information in supporting the development of plans for the adaptation of smallholder farmers and see the lack of scientific information as a key barrier for developing adaptation policies. It is also evident that policy makers at multiple levels (from technical managers to ministers) are keen to have more detailed information on climate change impacts and adaptation strategies to guide policy making. One key information gap is the lack of information on which farmers are most vulnerable to climate change, where they are located and which farmers have high capacity to respond to changes in climate. Information is also urgently needed on the costs and benefits of different adaptation practices that could be implemented by smallholder farmers to help them adapt to climate change (particularly in agricultural systems other than coffee and cacao). Additional research is needed to fill these gaps and ensure that policy makers have information on the expected impacts of climate change on farmers and farming systems, on farmers' vulnerability to climate change, and on the effectiveness of adaptation strategies for farmers.

Given the discrepancy between the perceived importance of scientific information for decision making and the current limited use of scientific information by policy makers, it is clear that additional steps are needed to promote the use of scientific and technical information in guiding and developing policies and plans. To the extent possible, future research on climate change and adaptation issues should be co-generated with policy makers and designed to address specific knowledge gaps and policy questions. In addition, scientific results need to be published in venues and formats that are accessible to policy makers, written in non-technical language that policy makers can understand and provide specific, policy-relevant recommendations for action. The generation of scientific information that is attuned to the needs of policy makers will greatly enhance the ability of policy makers to develop effective, evidence-based policies for climate change, including the much-needed policies and plans for helping smallholder farmers adapt to climate change.

Acknowledgments This study was conducted as part of the CASCADE project ("Ecosystem-based Adaptation for Smallholder Subsistence and Coffee Farming Communities in Central America"). This project is part of the International Climate Initiative (ICI). The German Federal Ministry for the Environment, Nature Conservation, Building and Nuclear Safety (BMUB) supports this initiative on the basis of a decision adopted by the German Bundestag. We thank the 105 participants who kindly responded to the online survey. We also thank members of the CASCADE project, Shyla Raghav, Jason P. Landrum and Ana Lucia Solano for discussions and insights and Maria Lopez, Fabiola Villa and Andrea Cruz for help with the administration of the survey. Funding for open access was provided by Conservation International's institutional Climate Change Team within the Global Strategy Grou p.

Open Access This article is distributed under the terms of the Creative Commons Attribution 4.0 International License (http://creativecommons.org/licenses/by/4.0/), which permits unrestricted use, distribution, and reproduction in any medium, provided you give appropriate credit to the original author(s) and the source, provide a link to the Creative Commons license, and indicate if changes were made.

\section{References}

Abbasi DR (2006) Americans and Climate change: closing the gap between science and action. Yale School of Forestry and Environmental studies, New Haven 
Adger WN, Agrawala S, Mirza MMQ, Conde C, O’Brien K, Pulhin J, Pulwarty R, Smit B, Takahashi K (2007) Assessment of adaptation practices, options, constraints and capacity. Climate Change 2007. In: Parry OF, Canziani JP, Palutikof PJ, Linden v d, Hanson CE (eds) Impacts, adaptation and vulnerability. Contribution of working group II to the fourth assessment report of the intergovernmental panel on climate change ML. Cambridge Univ. Press, Cambridge, pp. 717-743

Agrawala S, Broad K, Guston DH (2001) Integrating climate forecasts and societal decision making: challenges to an emergent boundary organization. Sci Technol Hum Values 26(4):454-477

Bushell S, Colley T, Workman M (2015) A unified narrative for climate change. Nat Clim Chang 5:971-973

Campbell DM, Redman S, Jrn L, Cooke M, Zwi AB, Rychetnik L (2009) Increasing the use of evidence in health policy: practice and views of policy makers and researchers. Aust New Zealand Health Policy 6(1):21

Cash DW, Clark WC, Alcock F, Dickson NM, Eckley N, Guston DH, Jager J, Mitchell RB (2003) Knowledge systems for sustainable development. Proc Natl Acad Sci 100(14):8086-8091

CEPAL (2012) La economía del cambio climático en Centroamérica. Impactos potenciales en aridez y meses secos http://www.cepal.org/mexico/cambioclimatico/documentos/ARIDEZ_BAJA.pdf

CEPAL (2013) Gestión Integral de Riesgos y Seguros Agropecuarios en Centroamérica y la República Dominicana: Situación Actual y Líneas de Acción Potenciales. United Nations http://repositorio.cepal.org/bitstream/handle/ 11362/27170/M20130038 es.pdf;jsessionid=86A8C32E0998E3C53B6CAFF82CAAA72A?sequence=1

Cote M (2011) Barriers to implementing climate adaptation plans: a survey of climate professionals across sectors. Association of climate change officers - climate adaptation working group. Washington, DC

Crone AJ, Baum RL, Lidke DJ, Sather DND, Bradley L-A, Tarr AC (2001) Landslides induced by hurricane Mitch in El Salvador: An inventory and descriptions of selected features. US Department of the Interior, US Geological Survey http://pdf.usaid.gov/pdf_docs/Pnacr105.pdf

Dabelko GD (2005) Speaking their language: how to communicate better with policy makers and opinion shapers - and why academics should bother in the first place. Int Environ Agreements 5:381-386

Devendra C (2007) Small farm systems to feed hungry Asia. Agriculture 36(1):7-20

Eakin H (2005) Institutional change, climate risk and the rural vulnerability. Cases from Central Mexico. World Dev 33:1923-1938

FAO (2011) Food security communications toolkit. Food and Agriculture organization of the United Nations, Rome

Field A (2007) Analysis of variance (ANOVA). In: Salkind N (ed) Encyclopedia of measurement and statistics. Sage Publications, Thousand Oaks, pp. 33-36

French S, Geldermann J (2005) The varied contexts of environmental decision problems and their implications for decision support. Environ Sci Pol 8(4):378-391

Fyfe A (2002) Bitter harvest, child labour in agriculture. International Labour Organization, Geneva

Gay C, Estrada F (2007) Cambio climático en México. Centro de Ciencias de la Atmósfera-UNAM Mexico http://ccaunam.atmosfcu.unam.mx/gcclimatico/documentos/cambio_climatico/publicaciones/aserca_ Cambio climatico_2007\%5B1\%5D-1-2.pdf

Goodman LA (1961) Snowball sampling. Ann Math Stat 32(1):148-170

Heller NE, Zavaleta ES (2009) Biodiversity management in the face of climate change: a review of 22 years of recommendations. Biol Conserv 142:14-32

Imbach P, Molina L, Locatelli B, Corrales L (2010) Vulnerabilidad de los servicios ecosistémicos hidrológicos al cambio climático en Mesoamérica - Latina. Turrialba, Costa Rica - Adaptación al cambio climático y servicios ecosistémicos en América CATIE http://agents.cirad.fr/pjjimg/bruno.locatelli@cirad.fr/Martinez_ 2010_Adaptation_servicios_ecosistemicos.pdf

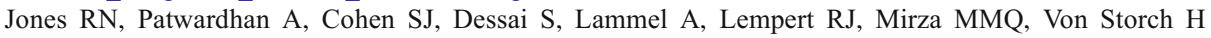
(2014) Foundations for decision making. In: Field CB, Barros VR, Dokken DJ, Mach KJ, Mastrandrea MD, Bilir TE, Chatterjee M, Ebi KL, Estrada YO, Genova RC, Girma B, Kissel ES, Levy AN, MacCracken S, Mastrandrea PR, White LL (eds) Climate change 2014: impacts, adaptation, and vulnerability. Part A: global and Sectoral aspects. Contribution of working group II to the fifth assessment report of the intergovernmental panel on climate change. Cambridge University Press, Cambridge, pp. 195-228

Kaplowitz MD, Hadlock TD, Levine R (2004) A comparison of web and main survey response rates. Public Opin Q 68(1):94-101

Kowal M, Delgado H (2010) Estudio sobre el cambio climático y la seguridad alimentaria y nutricional en Guatemala. AGRECO http://www.marn.gob.gt/sub/portal_cambio_climatico/docs/infin.pdf

Lobell DB, Burke MB, Tebaldi C, Mastrandrea MD, Falcon WP, et al. (2008) Prioritizing climate change adaptation needs for food security in 2030. Science 319:607-610. doi:10.1126/science.1152339

Maynard-Ford MC, Phillips EC, Chirico PG (2008) Mapping vulnerability to disasters in Latin America and the Caribbean 1900-2007. U.S. Geological Survey Open-File Report 2008-1294 http://pubs.usgs.gov/of/2008/ 1294/ofr2008-1294.pdf 
Mimura N, Pulwarty RS, Duc DM, Elshinnawy I, Redsteer MH, Huang HQ, Nkem JN, Sanchez RRA (2014) Adaptation planning and implementation. In: Field CB, Barros VR, Dokken DJ, Mach KJ, Mastrandrea MD, Bilir TE, Chatterjee M, Ebi KL, Estrada YO, Genova RC, Girma B, Kissel ES, Levy AN, MacCracken S, Mastrandrea PR, White LL (eds) Climate change 2014: impacts, adaptation, and vulnerability. Part A: global and Sectoral aspects. Contribution of working group II to the fifth assessment report of the intergovernmental panel on climate change. Cambridge University Press, Cambridge, pp. 869898

Ministerio Agropecuario y Forestal (2013a) Plan de Adaptación a la variabilidad y el Cambio Climático en el Sector Agropecuario, Forestal y Pesca en Nicaragua. Nicaragua Government, Managua, Nicaragua

Ministerio Agropecuario y forestal (2013b) Plan de Adaptación a la variabilidad y el Cambio Climático en el Sector Agropecuario, Forestal y Pesca en Nicaragua. Documento para el Plan de acción 2010-2015 de la Estrategia Nacional Ambiental y del Cambio Climático como un Plan de adaptación en los sectores agropecuario, forestal y pesca http://www.magfor.gob.ni/prorural/ IIMesa2012/PlanAdaptacion2013.pdf

Ministerio de Agricultura, Ganadería y Alimentación (2011) Manual de organización y funciones- nueva estructura. Guatemala

Ministerio de Ambiente, Energia y Telecomunicaciones (2009). Estratégia Nacional de Cambio Climático. 1.ed. San José

Ministerio de Medio Ambiente y Recursos Naturales. (2013). Estratégia Nacional de Cambio Climático. Ministerio de Medio Ambiente y Recursos Naturales, San Salvador, El Salvador

Ministry of the Environment and Natural Resources. (2013). NCCS (2013) National Climate Change Strategy. 10-20-40 Vision. Federal Government of Mexico, D.F., Mexico

Morss RE, Wilhelmi OV, Downton MW, Gruntfest E (2005) Flood risk, uncertainty, and scientific information for decision making: lessons from an interdisciplinary project. Bull Am Meteorol Soc 86(11):1593-1601

Morton JF (2007) The impact of climate change on smallholder and subsistence agriculture. Proc Natl Acad Sci 104(50):19680-19685

Moser SC, Luers AL (2008) Managing climate risks in California: the need to engage resource managers for successful adaptation to change. Clim Chang 87:S309-S322

Nagayets, O (2005) Small farms: Current status and Key trends. Abstract in: Proceedings of Research Workshop on the Future of Small Farms, Wye, UK, 26-29 June 2005. www.ifpri.org/sites/default/files/publications/ sfproc.pdf

Ojeda-Bustamante W, Sifuentes-Ibarra E, Íñiguez-Covarrubias M, Montero-Martínez M (2011) Impacto del cambio climático en el desarrollo y requerimientos hídricos de los cultivos. Agrociencia 45(1):1-11 http:// www.scielo.org.mx/pdf/agro/v45n1/v45n1a1.pdf

Picado Traña F (2003) Plan de Acción Nacional ante el Cambio Climático. Ministerio del Ambiente y los Recursos Naturales, Managua

R Core Team (2013) R: A language and environment for statistical computing. R Foundations for Statistical Computing, Vienna, Austria. URL http://www.R-project.org/

Rayner S, Lach D, Ingram H (2005) Weather forecasts are for wimps: why water resource managers do not use climate forecasts. Clim Chang 69:197-227

Sarachick ES, Shea E (1997) End to end seasonal to interannual prediction. The ENSO Signal 7:4-6

Sarewitz D, Pielke RA Jr. (2007) The neglected heart of science policy: reconciling supply and demand for science. Environ Sci Pol 10:5-16

Secretaria de Recursos Naturales y Ambiente (2010) Estratégia Nacional de Cambio Climático Honduras

Sheehan KB (2001) E-mail survey response rates: a review. J Comput-Mediat Commun 6(2). doi:10.1111/j.10836101.2001.tb00117.x

Stads, G-T (2008) Key trends in public agricultural research capacity and investments in Central America. Agricultural Science and Technology Indicators

Stads, G-T, Beintema, NM (2009) Public agricultural research in Latin America and the Caribbean. Investment and Capacity trends. ASTI Synthesis Report

Tribbia J, Moser SC (2008) More than information. What coastal managers need to plan for climate change. Environ Sci Pol 11:315-328

Uneke CJ, Ezeoha A, Ndukwe CD, Oyibo PG, Onwe F (2010) Development of health policy and systems research in Nigeria: lessons for developing countries' evidence-based health policy making process and practice. Healthcare Policy 6:48-65

UNEP (2013) Smallholders, food security and the environment. IFAD, UNEP, Rome 
United Nations Development Programme (UNDP) Bureau for Crisis Prevention and Recovery (BCPR) (2013) Climate Risk Management for Smallholder Agriculture in Honduras. New York, NY http://www.iisd.org/ pdf/2013/crm_honduras.pdf

Vorley B, Del Pozo-Vergnes E, Barnett A (2012) Small producer agency in the globalized market: making choices in a changing world. IIED. HIVOS, The Hague, London

WWF (2010) Cambio climático: Impactos y vulnerabilidad al cambio climático en México. COP16 http:// awsassets.panda.org/downloads/03_impactos_nacionales_e_internacionales_del_cambio_climatico 